\title{
LA DESAMORTIZACIÓN DE BIENES DE LAS COMUNIDADES CIVILES Y RELIGIOSAS Y LA REVOLUCIÓN MEXICANA DE 1910
}

\author{
THE CONFISCATION OF GOODS OF THE CIVIL AND RELIGIOUS COMMUNITIES AND THE
}

MEXICAN REVOLUTION OF 1910

Oscar Cruz Barney*

\begin{abstract}
Incuestionable es que no debe tolerarse la subsistencia de las comunidades de indígenas, procurándose por el contrario la repartición de los bienes de que han sido propietarios, y este es cabalmente uno de los principales preceptos de la ley de 25 de junio... ${ }^{1}$
\end{abstract}

\begin{abstract}
Resumen:
La propiedad de las comunidades indígenas en la Nueva España permitió, a través de un esquema de protección a la misma, que dichas poblaciones se desarrollasen con un grado de autonomía importante. Ese esquema de propiedad no se consideró compatible con la idea de igualdad constitucional en el siglo XIX, lo que llevó a los procesos de desamortización de bienes de comunidades civiles y religiosas. Dichas reformas legislativas se convirtieron en la semilla para la Revolución Mexicana de 1910.

Palabras-clave: Propiedad. Comunidades indígenas, civiles, religiosas.

Abstract:

The lands of the indigenous communities of New Spain allowed them, through a specific legal structure, to have an important grade of autonomy. This property structure was considered not compatible with the idea of equality established by the Constitutions during the XIX century. That leads to a number of legal reforms to force this communities to sell their lands. Those legal reforms became the seeds of the Mexican Revolution of 1910.
\end{abstract}

Keywords: Ownership. Indigenous communities. Civil communities. Religious communities.

\footnotetext{
Investigador del Instituto de Investigaciones Jurídicas de la UNAM, ocbarney@unam.mx.

1 Resolución de 19 de diciembre de 1856, en LABASTIDA, Luis G. Colección de leyes, decretos, reglamentos, circulares, órdenes y acuerdos relativos a la desamortización de los bienes de corporaciones civiles y religiosas y a la nacionalización de los que administraron las últimas. México: Tipografía de la Oficina Impresora de Estampillas, 1893. p. 29.
} 
1. Introducción: conquista y propiedad de la tierra

La conquista de México-Tenochtitlán, además de la superioridad militar, aprovechó las concepciones míticas de los indígenas y en el caso de México, el problema existente con los tlaxcaltecas, antiguos enemigos de los aztecas o mexicas.

Se dio inicio a un proceso de descomposición de la cultura indígena, empezando con la pérdida de las élites sociales. Los conquistadores celebraron una serie de alianzas con los líderes indígenas, que fueron los primeros en ser evangelizados, con la consiguiente incorporación de éstos a la cultura occidental.

Para el siglo XVIII las familias pertenecientes a la nobleza indígena habían descendido social y económicamente, en parte por la pérdida de sus tributarios, que pasaron a tributar de acuerdo con la administración de los encomenderos. ${ }^{2}$

Lo primero que sufrieron los aztecas fue la deformación de sus costumbres, que fueron mal interpretadas por los conquistadores, como el creer que el cacique ${ }^{3}$ era un señor feudal; así, se le impuso características ajenas al mismo. Se le dio el cargo de cacique a los antiguos tecuhtlis, o en el caso de Tenochtitlan, al cihuacóatl. En ocasiones, en razón del desconocimiento, se les otorgó el cargo a viejos funcionarios de más bajo rango. ${ }^{4}$

Por otra parte, el cargo dejó de ser el resultado de una elección para convertirse en hereditario, lo que transformó al antiguo tecuhtli en señor, con el consiguiente problema de legitimidad.

En un principio se les otorgaron una serie de funciones gubernativas, judiciales, fiscales, etc. Los principales de los diversos barrios que dependían de la cabecera auxiliaban a los caciques. Hacia mediados del siglo XVI, se ordenó que los señores indígenas fueran llamados principales y que en los pueblos de indios estos principales tuvieran funciones de caciques. ${ }^{5}$ Además, el régimen municipal europeo se introdujo en los pueblos indígenas, los gobernadores y los alcaldes ${ }^{6}$ asumieron las

2 GIBSON, Charles. Los aztecas bajo el dominio español (1519-1810). Trad. Julieta Campos. México: Siglo XXI, 1967. p. 196.

3 Término tomado por los españoles del lenguaje de los nativos de la Hispaniola, que calificaba al jefe tribal local. Este término fue aplicado en México hasta llegar a convertirse en sinónimo de señor feudal. Véase Gonzalo Aguirre Beltrán. Formas de gobierno indígena. México: Instituto Nacional Indigenista, 1981. p. 33.

4 SOlÓRZANO Y PEREIRA, Juan de. Política indiana. Compañía Ibero-Americana de Publicaciones. Madrid: 1930. t. I, libro II, cap. XXVII, n. 1.

5 ENCINAS, Diego de. Cedulario indiano. ed. facsimilar de la única de 1596. Madrid: Ediciones de Cultura Hispánica, 1945. t. IV, f. 291.

6 En 1601 fueron nombrados cinco alcaldes en México: "Martín Suárez Cozcacuauh, de San Juan, que era fiscal; Miguel Sánchez Hueton, de San Juan, que era regidor; don Bartolomé Francisco Xochiquen, de San Pablo, que fue alcalde por segunda vez; don Miguel Sánchez, de Atzacualco, que fue alcalde por sexta vez; y 
funciones gubernativas y judiciales, a los caciques únicamente se les dejó las funciones de recaudación de tributos y la gestión de todo lo relativo al servicio personal. ${ }^{7} \mathrm{El}$ cargo de gobernador empezó a diferenciarse del de tlatoani, por lo que los dos cargos lo desempeñaban distintas personas. ${ }^{8}$

El cacique estaba sujeto a la autoridad española regional, al corregidor o al alcalde mayor. En sus inicios, dependía del encomendero.

Los pueblos de indios estaban obligados a sostener a su señor entregándole anualmente una determinada cantidad de pesos, la siembra de maíz, algodón, etc., y el servicio personal en su casa. Además, el señor podía utilizar el don castellano y era considerado hijodalgo, con derecho a montar a caballo, usar armas y, finalmente, la condición de nobleza. Este ennoblecimiento del cacique trajo consigo un fortalecimiento de los antiguos nobles o piles.

Por otra parte, las costumbres indígenas se mezclaron con las españolas, como es el caso del cabildo indígena y el cabildo de españoles, aunque las costumbres indígenas poco a poco fueron desapareciendo, ${ }^{9}$ o bien, surgieron nuevas costumbres indígenas alrededor del derecho escrito, ya sea conforme a él, suplementándolo o incluso contradiciéndolo. ${ }^{10}$

La Corona de Castilla, antes que eliminar el derecho indígena precortesiano buscó su incorporación al nuevo sistema jurídico implantado, aprobando y confirmando la vigencia de las costumbres que fueran compatibles con los intereses de la Corona y del cristianismo. En la Recopilación de leyes de los reynos de las Indias de 1680, publicada en 1681 , se estableció que

...las leyes y buenas coftumbres, que antiguamente tenias los Indios para fu buen govierno y policia, y fus ufos y coftumbres obfervadas y guardadas defpués que fon chriftianos) y que no fe encuentran con nueftra Sagrada Religión, ni con las leyes de efte libro, y las que han hecho y ordenado de nuevo fe guarden y executen, y fiendo neceffario, por la prefente las aprobamos y confirmamos, con tanto, que Nos podamos añadir lo que fuéremos fervido, y nos pareciere que conviene al fervicio de Dios nueftro

Gabriel Suárez, de Santa María, que fue alcalde por segunda vez.” Véase Domingo de Chimalpáhin, Diario, Paleografía y traducción Rafael de Tena. México: Consejo Nacional Para la Cultura y las Artes, 2001. Colección "Cien de México", p. 81, ver asimismo la p. 207.

7 ZAVALA, Silvio; MIRANDA, José. Instituciones indígenas en la colonia. In: Métodos y resultados de la politica indigenista en México. México: Instituto Nacional Indigenista, 1954. p. 60.

8 GIBSON, Charles. op. cit., p. 171. Las actividades de dichos gobernadores y principales pueden verse claramente en CHIMALPÁHIN, Domingo de. Diario. Paleografía y traducción Rafael de Tena. México: Consejo Nacional Para la Cultura y las Artes, 2001. Colección "Cien de México".

9 Este tema se abordará al tratar el derecho indiano.

10 ZAVALA, Silvio; MIRANDA, José. op. cit., p. 62. 
Señor, y al nueftro, y á la confervacion y policia Chriftiana de los naturales de aquellas Provincias, no perjudicando á lo que tienen hecho, ni á las buenas y juftas coftumbres y Eftados fuyos. ${ }^{11}$

Ello no impidió que los indígenas abandonaran sus costumbres, si así lo decidían, en beneficio del nuevo sistema. ${ }^{12}$

Así, por ejemplo, entre los indígenas se escogían los jueces pedáneos, regidores, alguaciles, escribanos y otros ministros de justicia, quienes podían administrar la justicia de acuerdo con sus costumbres y dirimir los pleitos de menor cuantía en sus pueblos. $^{13}$

La evangelización indígena iba a la par del proceso de culturización, ardua tarea efectuada en la mayor parte en la propia lengua de los indios. ${ }^{14}$ Los caciques fueron los primeros en ser evangelizados y en aprender el castellano por el ejemplo que darían a los demás indígenas, política que dio magnificas resultados. ${ }^{15}$

El 6 de enero de 1536 se inauguró en México el colegio franciscano de Santiago Tlaltelolco, fundado en el arrabal de ese mismo nombre el día de la Santa Cruz, presidida la ceremonia por el primer virrey de la Nueva España, don Antonio de Mendoza y bajo la dirección de fray Juan de Zumárraga. Se enseñaba lectura, escritura, música, latín, retórica, lógica, filosofía y medicina indígena. El más famoso latinista egresado del colegio fue Antonio Valeriano, a quien se comparó con Cicerón, alumno de fray Bernardino de Sahagún. ${ }^{16}$

La propiedad de la tierra podía corresponder no sólo a los particulares, sino también a las comunidades y corporaciones.

a) Propiedad privada. El nacimiento del derecho de propiedad sobre tierras a título particular se manifestó en las capitulaciones, instrucciones y ordenanzas sobre descubrimientos, conquistas y poblaciones. Por merced del rey y por el repartimiento gratuito de la tierra se perfilaba la propiedad particular en los primeros mementos del siglo XVI. Una vez que el particular cumplía con ciertas condiciones, como edificar dentro

11 Recopilación de Leyes de los Reinos de las Indias. Facsimilar. Madrid: Julián de Paredes, 1681. Madrid: Ediciones Cultura Hispánica, 1973. Lib. II, tit.I, L.IIII. (Real cédula del 6 de agosto de 1555).

12 MARGADANT, Guillermo Floris. Introducción a la historia del derecho mexicano. 10. ed. México: Esfinge, 1993. p. 36.

13 SOLÓRZANO Y PEREIRA, Juan de. op.cit. t. I, libro II, cap. XXVII, n. 12. La cédula se puede ver en Diego de Encinas, Cedulario indiano, t. IV, fol. 274.

14 ZORAIDA VÁZQUEZ, Josefina. La imagen del indio en el español del siglo XVI. Xalapa: Biblioteca Universidad Veracruzana, 1991.p. 92.

15 SOLÓRZANO Y PEREIRA, Juan de. op. cit., t. I, libro II, cap. XXVI, n. 19-20 y libro II, cap. XXVII, n. 29.

16 RICARD, Robert. La conquista espiritual de México. Trad. Ángel María Garibay. México: Jus-Polis, 1947. p. 123-124 y 392-402. 
de los cinco años siguientes en el solar que le fue concedido, o bien que se trabajara la tierra, o que se comprometiera a no donar sus bienes a la Iglesia. Además, era necesario respetar el derecho a las minas de la Corona y no afectar los intereses existentes de las comunidades indígenas. ${ }^{17}$

En la Nueva España el repartimiento lo hizo también la Real Audiencia desde 1531 , y el virrey desde 1535 , con la necesaria confirmación real. ${ }^{18}$ La tierra se convirtió en el media de pagar el esfuerzo del conquistador, si bien la Corona repartió tierra realenga a todo particular, fuera criollo, mestizo o recién llegado a las Indias, que la pidiera con voluntad de colonización. ${ }^{19}$

Si bien las tierras se entregaban en forma gratuita en un inicio, cada vez fue más frecuente que la Corona las vendiera o bien, tras la reforma agraria de 1591, se obtenía dinero de la composición de los títulos de propiedad que tuvieran defectos, mediante el pago de una multa o aportación económica. ${ }^{20}$ Esta composición de 1691 buscaba la corrección de las irregularidades verificadas en la posesión de la tierra y obtener recursos para la Corona, exigiendo a los poseedores la exhibición de sus títulos a solicitud de la autoridad. ${ }^{21}$ La composición se repitió en 1631, 1635, 1640 y 1643 con el fin de recabar fondos. ${ }^{22}$

El primero de julio de 1692 se creó la Superintendencia del Beneficio y Composición de Tierras o Juzgado de Tierras, encargado de los negocios de este rubro, de la corrección de los problemas de propiedad, composición y venta. ${ }^{23}$ Además, la superintendencia estaba encargada de recaudar lo que a la Real Hacienda debían los propietarios rurales.

El superintendente estaba facultado para nombrar subdelegados, que conocerían en el ámbito de su jurisdicción las causas sobre composiciones, los cuales actuarían como jueces de tierras.

En 1715 se establecieron con claridad las funciones del juzgado: recaudar todo lo que se debiera de compras de villas, lugares, jurisdicciones, dehesa, bosques, plantíos, alcabalas, pechos y derechos que tocaran a la Real Hacienda. Además, debía llevar la dirección de las tierras, sitios, aguas y lo demás perteneciente al Real Patrimonio y se poseyera sin título y justa causa. Se encargaba también de la venta de baldíos. En

\footnotetext{
17 MARGADANT, Guillermo Floris. Introducción..., cit., p. 89.

18 SOLANO, Francisco de. Cedulario de tierras. Compilación de legislación agraria colonial (1497-1820). Instituto de Investigaciones Jurídicas. México: UNAM, 1984. p. 28.

19 Ibidem, p. 21.

$20 \quad$ Ibidem, p. 18 y 42.

21 Rec. Ind. lib. IV, tít XII, ley 14.

22 SOLANO, Francisco de. Cedulario..., cit., p. 50.

23 Ibidem, p. 61.
} 
1736 se dieron instrucciones generales a los jueces de la composición de tierras, y se inició la composición de tierras de indios e Iglesia. ${ }^{24}$

El 15 de octubre de 1754 se produjo una nueva reforma agraria que se encargó de la revisión de los títulos de propiedad posteriores a 1700, y admitió la prescripción de las cultivadas antes de ese año. ${ }^{25}$

En Indias se intentó evitar el desarrollo del latifundio. Sin embargo, éste se produjo por distintas vías, una de las cuales fue el mayorazgo, que consistía en una institución del derecho castellano regulada por la Leyes de Toro de 1505.

Ésta consistía en "el derecho de suceder en los bienes dejados por el fundador con la condición de que se conserven íntegros perpetuamente en su familia para que los lleve y posea el primogénito más próximo por orden sucesivo". ${ }^{26}$ Con él, los bienes salían del comercio y se perpetuaban dentro de un patrimonio familiar.

b) La propiedad comunal de ciudades, villas y lugares. Junto con la formación de la propiedad particular, nació la propiedad de las ciudades y villas a las que se les adjudicaban solares de propios y tierras, junta con una declaración de aprovechamiento comunal de montes, pastos y aguas.

c) La propiedad corporativa: propiedad de la Iglesia y primeros intentos de desamortización. Desde los inicios de la expansión española en Indias, la administración quiso evitar que se repitieran algunas de las situaciones sociales y económicas propias de la Península en cuanto a la tenencia de la tierra, además de intentar fortalecer la capacidad fiscal del Estado. Se pretendió impedir las grandes concentraciones de tierras en manos de la Iglesia, por lo que desde las primeras mercedes de tierras se condicionaba al beneficiario a no vender a hospital, iglesia, monasterio o persona eclesiástica. Pese a los esfuerzos estatales, la acumulación se produjo, lo que dio lugar, en la segunda mitad del siglo XVIII, a procesos de desamortización de bienes.

En el trazado cuadriculado de los núcleos urbanos de reciente creación se destinaban espacios a los templos y conventos de las órdenes mendicantes franciscana, dominica, de Nuestra Señora de la Merced y de los agustinos, y el centro se reservaba a la catedral o iglesia mayor. El modo de vida austero propio de las órdenes mendicantes, con escasas propiedades para su sostenimiento, se mantuvo durante una parte del siglo XVI, que fue de evangelización en manos del clero regular.

Con el clero secular se inició una serie de donaciones de las tierras que los indios destinaban a sus sacerdotes y temples, que pasaron a manos de las iglesias

$24 \quad$ Ibidem, p. 68.

25 PÉREZ Y LÓPEZ, Antonio Xavier. Teatro de la Legislación Universal de España e Indias. Imprenta de MADRID: Antonio Espinoza, 1791-1798. XXVIII tomo V, p. 217-225.

26 Véase la cita que hace de Luis de Molina, Bartolomé Clavero en su trabajo Mayorazgo. Propiedad feudal en Castilla 1369-1836. 2. ed. Madrid: Siglo XXI, 1989. p. 211. 
para su sostenimiento. Además, a pesar de las precauciones tomadas por el Estado en materia de ventas y donaciones de tierras a las iglesias por los particulares, con el tiempo y desde la segunda mitad del siglo XVI se abrió la posibilidad de que iglesias y monasterios poseyeran tierras cedidas o vendidas por los particulares, no realengas, las cuales al momento de entrar en el dominio eclesiástico dejaban de contribuir fiscalmente al Estado, es decir, caían en manos muertas.

Esta situación obligó en 1576 a repetir la prohibición a los particulares de donar o vender sus tierras a la Iglesia y se ordenó el levantamiento de un censo, que se llevó a cabo en 1577 y 1579.

La propiedad rural de la Iglesia y de los eclesiásticos en lo individual aumentó de manera considerable, más aún con la presencia de la Compañía de Jesús, que dio a sus propiedades un intense aprovechamiento agrícola y asistencial. De todos modos, las prohibiciones a los seglares que vendieran sus tierras al clero se sucedían.

En el siglo XVII las órdenes y congregaciones estaban en posesión de grandes extensiones rurales que, al estar exentas del pago de impuestos, dañaban al Estado y también al clero diocesano que dejaba de percibir los diezmos.

Con la creación de la Superintendencia del Beneficio y Composición de Tierras, en 1692, se intentó corregir esta situación, por lo que la composición alcanzó las tierras de los eclesiásticos. Gracias a ello, la Iglesia pagó las cantidades que en los casos de ocupación irregular correspondía y el Estado logró por primera vez realizar una cuantificación de los bienes rústicos de ésta.

En 1735 se puso fin a la situación de privilegio de la Iglesia frente al Estado en materia de impuestos, ya que mediante un concordato suscrito entre la Santa Sede y el Estado se reconocía que habrían de pagar impuestos todas las propiedades nuevas que fueran incorporadas al patrimonio de las instituciones eclesiásticas.

Se pensaba que las tierras en poder de la Iglesia, de los municipios o de otras "manos muertas" rendían poco, que quedaban al margen del libre comercio y que se sustraían, por el carácter privilegiado de sus propietarios, a todo tipo de tributación en favor de la Hacienda Real. ${ }^{27}$

El primero de los grandes actos de desamortización se produjo con la expulsión en 1762 de la Compañía de Jesús de las posesiones españolas, lo que tuvo como consecuencia un recorte muy importante de la actividad económica y productiva en el mundo rural. La desamortización continuó a principios del siglo xix; en 1804 se creó la Junta de Consolidación para la venta de fondos rústicos y urbanos que sostenían algunas

TOMÁS Y VALIENTE, Francisco. El marco político de la desamortización en España. Barcelona: Ariel, 1971. p. 15 . 
asociaciones piadosas. Con esto se suscitó una serie de cambios que propiciaron en un momento dada los inicios del movimiento insurgente. ${ }^{28}$

\section{Los bienes de las comunidades indígenas}

Las tierras indígenas se incorporaron a las estructuras españolas con criterios y medidas agrarias diferentes de las prehispánicas, con reconocimiento de la propiedad de los indios sobre sus tierras y variación de la distribución de acuerdo con el grado de desarrollo cultural de las poblaciones indígenas.

Las autoridades virreinales se encargaron de reorganizar la situación de las diferentes etnias. Las concentraron en unidades urbanas a partir del año 1500 y les otorgaron nuevas tierras; además, promovieron la colonización dirigida, de lo que se derivaron títulos de propiedad que debían protegerse en contra de los posibles abusos. Muchas de estas poblaciones nuevas se situaron cerca de los asentamientos originales; otras fueron de nueva creación mediante el traslado de grades grupos de pobladores a otros lugares, otorgándoles espacios comunales, tierras para el cacique y los particulares. Estos pueblos de indios fueron modelos aplicados uniformemente con las diferentes etnias y con resultados diferentes. ${ }^{29}$

Se buscó que el indígena fuera un campesino capaz y autosuficiente, a fin de abastecer los núcleos urbanos y las zonas de explotación minera. Alrededor de los pueblos indios se extendieron las propiedades ganaderas, de hacienda y los latifundios. Los asentamientos así organizados por los españoles facilitaban no sólo contar con la mano de obra necesaria, sino también la evangelización y el control fiscal.

Mediante la Real Cédula del 10 de junio de 1540 nació la política de las reducciones de indios de manera sistemática, con un programa urbanizador que hizo que la colonización se realizara en y desde las ciudades. En 1548 se ordenó al virrey de Nueva España que procediera a reunir en pueblos grandes a los indios de Yucatán y Cozumel, política que se extendió a todo el territorio novohispano en 1549 mediante la Real cédula del 9 de octubre de 1549 a la Audiencia de la Nueva España ordenando sean hechos pueblos de indios, con autoridades municipales elegidas entre el vecindario. ${ }^{30}$ Esta disposición se repitió en la instrucción dada por el monarca al virrey Luis de Velasco en 1550 y se insistió en ello en 1560 y 1578.

Como incentivos para el traslado, al indígena se le ofrecían tierras nuevas y más extensas, con mayores recursos. Los misioneros se encargaron de esta labor

\footnotetext{
28 SOLANO, Francisco de. Cedulario..., cit., p. 90-96.

29 SOLANO, Francisco de. Cedulario..., cit., p. 76-77.

30 Documento n. 49 en el Cedulario..., de Francisco de Solano y en Encinas, t. IV, f. 272.
} 
de convencimiento al cacique y a la nobleza indígena con el ofrecimiento a él y a la comunidad de ventajas económicas y sociales. El misionero tuvo que enfrentarse además con el encomendero, pues buena parte de esa población indígena dispersa ya estaba encomendada.

El trazo de los pueblos de indios se hacía de acuerdo con la misma estructura urbana que los pueblos de españoles: la cuadrícula del terreno. Las poblaciones variaban de 300 a 400 vecinos sobre un espacio de 500 varas medidas desde el centro del pueblo a los cuatro vientos, que serían las tierras para vivir y sembrar, denominado fundo legal a partir del siglo XVIII, guardando además una distancia mínima de mil varas entre un fundo y un asentamiento de españoles. ${ }^{31}$ En 1687 se aumentó el fundo legal a 600 varas, pero medidas desde la última case, además de que se aumentó la distancia mínima entre un asentamiento de indios y de españoles a 1,100 varas. Esto se modificó en 1695 a causa de los ganaderos españoles, quienes lograron que la medición se hiciera de nuevo desde el centro del pueblo de indios. ${ }^{32}$ Los terrenos situados después del fundo legal eran los comunales y detrás de ellos el límite de las 1,100 varas.

Por su parte, la propiedad privada indígena subsistió y la Corona la protegió al prohibir, en 1503, que se vendiera a cambio de cuentas de vidrio: y cosas semejantes de poco valor, sino a precios justos. Los caciques cometieron fraudes sin cesar mediante la venta de tierra comunal, lo que volvió rígidos los procedimientos de venta de tierras de indios en 1571, ya que se exigió autorización para ello. En ventas menores de 30 pesos de oro bastaba la autorización del juez ordinario; en las mayores debía hacerse mediante almoneda pública. ${ }^{33}$

Es importante señalar que los bienes de la comunidad no podían enajenarse, y en 1781 la Corona aclaró que los indios tenían solamente el dominio útil respecto de ellas y extendió la prohibición a los de particulares. Podían testar disponiendo de sus bienes por esa vía, pero a falta de herederos, sucederla al pueblo de indios, nunca a españoles.

A los caciques los consideraron equivalentes jerárquicos de los hidalgos españoles, por lo que se les concedió cierto número de tierras en cada pueblo de indios, más la mano de obra respectiva. Estas diferencias trajeron consigo multitud de pleitos entre los macehuales y sus caciques por la posesión de tierras comunales. ${ }^{34}$

Los lugares donde se fundaren los pueblos de indios debían tener comodidad de aguas, tierras y montes, entradas y salidas, labranzas y un ejido de una legua de largo

\footnotetext{
$31 \quad 1000$ varas equivalen a 838 metros.

32 SOLANO, Francisco de. Cedulario..., cit., p. 84-85.

33 Rec. Ind. lib. VI, tít. 1, ley 27.

34 SOLANO, Francisco de. Cedulario..., cit., p. 89-90.
} 
a fin de que los indios pudiesen tener sus ganados sin que se revolviesen con otros de los españoles. $^{35}$

Es decir, cada pueblo de indios tendría y efectivamente tuvo dos tipos de tierras: las tierras comunales compuestas por las aguas, tierras y montes, entradas, salidas y labranzas y las ejidales, compuestas por un ejido de una legua de largo para el ganado.

En la Recopilación de leyes de los Reinos de las Indias de 1680 se establecería que uno de los oidores de la Real Audiencia correspondiente tenía que salir a visitar la tierra de su distrito y las ciudades y pueblos de él, para informarse de la calidad de la tierra, número de pobladores y posibles medios para mejorar su sustento. Era necesario procurar que los indios tuvieran bienes de la comunidad, así como de que plantaran árboles. ${ }^{36}$

Además, los indios reducidos a los pueblos mantendrían sus tierras y propiedades privadas que dejaren fuera de las tierras de la nueva población. ${ }^{37}$ En cada pueblo de indios habría un alcalde indígena y si el número de casas era mayor de 80, dos alcaldes y dos regidores también indios. ${ }^{38}$

Se dispuso además que la venta, beneficio y composición de tierras debía de hacerse de manera tal que a los indios se les debía dejar "con sobra" todas las que les pertenecieren, así en lo particular como por comunidades. Las aguas y riegos, y las tierras en donde hubiesen hecho acequias u otro cualquier beneficio, debían reservarse en primer lugar a los indios y por ningún caso se podían vender o enajenar. ${ }^{39}$ En las composiciones de tierras las comunidades indígenas debían ser preferidas. ${ }^{40}$

Mediante Reales Cédulas de 4 de junio de 1687 y 12 de junio de 1695 se estableció que a los pueblos de indios de la Nueva España debía dárseles todas las varas de tierra que fuesen necesarias para que los indios vivan y siembren sin escasez ni limitación. ${ }^{41}$

Todos los bienes de las comunidades indígenas que "el cuerpo y colección de Indios de cada Pueblo tuviere" debían entrar en las Cajas de Comunidad para que de allí se gastare lo preciso en beneficio común y se atendiera a su conservación y aumento. ${ }^{42}$

\footnotetext{
35 Ley VIII, Tít. III, Lib.VI, de la Recopilación de Leyes de los Reinos de las Indias. Madrid: Viuda de Joaquín Ibarra, 1791.

36 Rec. Ind., lib. II, tít. XXXI, ley LX.

37 Ley IX, Tít.III, Lib.VI, Rec.Ind.

38 Ley XV, Tít.III, Lib.VI, Rec.Ind.

39 Ley XVIII, Tít. XII, Lib.IV, Rec.Ind.

40 Ley XIX, Tít. XII, Lib.IV, Rec.Ind.

41 Recopilación Sumaria de todos los autos acordados de la Real Audiencia y Sala del Crimen de esta Nueva España, por el doctor Eusebio Bentura Beleña, impresa en México por Felipe de Zúñiga y Ontiveros, México, 1797, disposición 382 del tercer foliaje, t. I.

42 Ley II, Tít. IV, Lib.VI, Rec.Ind.
} 
La plata que resultare de los bienes, censos y rentas de la Comunidad solamente podía gastarse en lo que se dirigiese al descanso y alivio de los indios, en su provecho y utilidad. ${ }^{43}$

Las Cortes de Cádiz expidieron el 9 de noviembre de 1812 el Decreto CCVII Abolición de las mitas. Otras medidas a favor de los Indios ${ }^{44}$ por el que se ordenó la repartición de tierras a los indios casados o mayores de 25 años fuera de la patria potestad. Las tierras se tomarían de las inmediatas a los pueblos que no fueren de dominio particular o comunitario. Si las tierras comunales eran muy cuantiosas con respecto a la población del pueblo a que pertenecían, se repartiría cuando más hasta la mitad de dichas tierras, debiendo tener conocimiento de dichos repartimientos las diputaciones provinciales.

\section{El siglo XIX, las Leyes de Reforma y la idea de la codificación}

Con la Declaración de los Derechos del Hombre y del Ciudadano de 1789, ${ }^{45}$ frente a la concepción jurídica del antiguo régimen, existen sólo dos valores políticoconstitucionales: el individuo y la ley como expresión de la soberanía de la nación.

A partir del siglo XVIII se va a considerar, cada vez con mayor fuerza, que la ley es la única fuente legítima del derecho, única capaz de expresar la voluntad general y por ello se impone por encima de cualquier otra forma de producción jurídica, debilitando a las demás, "el viejo pluralismo jurídico, que tenía a sus espaldas, aunque con varias vicisitudes, más de dos mil años de vida, se sofoca en un rígido monismo." ${ }^{46}$ En este sentido, la división de poderes será el cimiento para asignar la producción jurídica al Poder Legislativo, que se identifica como titular de la soberanía popular. Así, la voluntad general será expresada a través de la Representación y ésta se expresa a través de la Ley, "fundamento material de su lugar en la jerarquía normativa". ${ }^{47}$ La codificación sostiene la idea de superar el particularismo jurídico y afirma la autoridad del Estado. ${ }^{48}$

43 Ley XIIII, Tít. IV, Lib.VI Rec. Ind.

44 Decreto CCVII Abolición de las mitas. Otras medidas a favor de los Indios, en Colección de los decretos y órdenes que han expedido las Cortes Generales y Extraordinarias. Reimpresa de Orden del Gobierno. Sevilla: Imprenta Mayor de la Ciudad, 1820. t. 3, p. 161-162.

45 Sobre los antecedentes de la Declaración véase GAZZANIGA, Jean Louis. La dimension historique des libertés et droits foundamentaux. In: CABRILLAC, Remy; FRISON-ROCHE, Marie-Anne; REVET, Thierry (Coord.). Libertés et droits fondamentaux. 8. ed. París: Dalloz, 2002. p. 16-23. Para la evolución de los derechos del hombre resulta de interés la obra de DUFOUR, Alfred. Droits de l'homme droit naturel et histoire. Paris: Presses Universitaires de France, 1991.

46 GROSSI, Paolo. Mitología jurídica de la modernidad. Trad. Manuel Martínez Neira. Madrid: Trotta, 2003. p. 75 .

47 CABO MARTÍN, Carlos de. Sobre el concepto de ley. Madrid: Ed. Trotta, 2000. p. 20.

48 DICKMANN, Renzo. Codificazione e processo legislativo. In: COSTANZO, Pasquale (Coord.). Codificazione del diritto e ordinamento costituzionale. Napoli: Facoltá di Giurisprudenza della Universitá di Camerino, 1999. p. 61. 
El código deberá ordenar y orientar la libertad e igualdad de los individuos exigida por el Derecho Natural. En México, la codificación significó la creación de una igualdad formal de la sociedad, sin poder borrar una desigualdad material existente. ${ }^{49}$

Ya en la Constitución de Apatzingán de $1814,{ }^{50}$ se estableció entre otros puntos que la felicidad del pueblo consiste en el goce de la igualdad, la seguridad, la propiedad y la libertad. El Acta Constitutiva y de Reformas del 21 de mayo de 1847 contiene, entre otras, la idea de que para asegurar los derechos del hombre, reconocidos por la Constitución, una ley habría de fijar las garantías de libertad, seguridad, propiedad e igualdad de que gozaban todos los habitantes de la República, así como los medios de hacerlas efectivas.

En medio del proceso y esfuerzos codificadores, se producen los ajustes que llevarán a la expedición de las leyes de Reforma. El ideal de la igualdad jurídica debía de pasar por la igualdad en las formas de propiedad de la tierra. Aquí las corporaciones civiles y religiosas habrían de sufrir las consecuencias de estos cambios.

Se considera que la Guerra de Tres Años es continuación de la de Ayutla, y se caracterizó, como la anterior, por un levantamiento popular que se enfrentó al ejército profesional. El movimiento de Ayutla estaba dirigido por los moderados, que trataban de alcanzar la reforma persuasiva y paulatinamente; el de la Guerra de los Tres Años fue encabezado por los puros, que van consumar la renovación. En este sentido, los moderados, que habían cumplido ya su destino histórico, se retiraban del escenario político ante el fracaso de su intento conciliatorio; así quedaban frente a frente los liberales y los conservadores, con ideas definidas y en principio irreconciliables.

La administración de Félix Zuloaga se formó con elementos conservadores y su primera acción fue declarar insubsistentes las disposiciones reformistas. El 20 de diciembre de 1858 se reveló en Ayotla el general conservador Miguel Echeagaray, encargado de atacar a Veracruz. Él reprobó tanto la Constitución de 1857 como el programa del gobierno de México y proclamó la reunión de una asamblea constituyente. La guarnición de la capital secundó el plan y Zuloaga renunció. En su lugar designó al general Manuel Robles Pezuela.

El 1o. de enero de 1859 se aprobaron las bases conforme a las cuales se propondría a los contendientes que se sometieran a la voluntad de la Nación y fue organizado el gobierno provisional. Se designó a Miramón presidente de la República. El día 3 se aprobó la convocatoria de elección del Constituyente, facultado para adoptar

49 En este sentido TAU ANZOATEGUI, Víctor. La codificación en la Argentina, 1810-1870. Mentalidad social e ideas jurídicas. 2. ed. Buenos Aires: Librería-Editorial Emilio J. Perrot, 2008. p. 18.

50 México ha tenido los siguientes textos constituciones: 1812, 1814, 1824, 1835, 1836, 1843, 1847, 1853, $1857,1858,1865$ y 1917. 
la Constitución que estimase conveniente entre las que habían regido anteriormente y hacer en ella las reformas consideradas oportunas o bien para expedir una nueva. Desde luego, se presuponía que la solución debía ser aceptada por los liberales y conservadores, representados unos por Juárez y otros por Miramón.

Por su parte, Benito Juárez desconoció lo actuado en la capital y el ejército conservador se sometió a Miramón, quien restituyó en la presidencia a Zuloaga y fue designado por éste su sustituto.

Benito Juárez estableció el gobierno constitucional fuera de la capital, en la ciudad de Guanajuato. ${ }^{51}$ Estaba integrado por Melchor Ocampo, Guillermo Prieto, Manuel Ruiz y León Guzmán. De allí se trasladó a Guadalajara, posteriormente a Colima y finalmente embarcó en Manzanillo el 11 de abril de 1858, en compañía de sus ministros, para arribar el 4 de mayo a Veracruz, donde fue recibido por el gobernador Gutiérrez Zamora; así, el gobierno constitucional se instaló en el puerto.

En el seno del grupo liberal que rodeaba a Juárez se presentaron diferencias en cuanto al camino por seguir: por una parte Miguel Lerdo de Tejada, secundado por Gutiérrez Zamora y por Manuel Romero Rubio, representante de González Ortega, exigía la expedición inmediata de la legislación reformista, particularmente la que se relacionaba con la nacionalización de los bienes del clero. Por la otra, Melchor Ocampo opinaba que la expedición de dichas disposiciones convertiría la lucha en guerra religiosa, por lo que opinaba debía aplazarse hasta haber asegurado el triunfo. En esos momentos arribó a Veracruz Santos Degollado, procedente del frente de combate a favor de la reforma. Fue él quien decidió a Juárez a expedir, el 7 de julio de 1859, el Manifiesto del gobierno constitucional a la nación, en donde se expresaba el programa de reforma. ${ }^{52}$ En dicho Manifiesto se decidió, a fin de terminar con los elementos que servían de apoyo al clero, que a su vez estaban del lado del bando conservador, lo siguiente:

1. Adoptar como regla general invariable la más perfecta independencia entre los negocios del Estado y los puramente eclesiásticos.

2. Suprimir todas las corporaciones de regulares del sexo masculino, sin excepción alguna, secularizándose los sacerdotes que actualmente hay en ellas.

3. Extinguir igualmente las cofradías, archicofradías, hermandades, y en general todas las corporaciones o congregaciones que existen de esa naturaleza.

51 GARCÍA GRANADOS, Ricardo. La Constitución de 1857 y las Leyes de Reforma en México. Estudio histórico-sociológico. México: Tipografía Económica, 1906. p. 57.

52 El texto del Manifiesto en TENA RAMÍREZ, Felipe. Manifiesto del gobierno constitucional a la nación del 7 de julio de 1859, en Leyes fundamentales de México. 1808-1989. 15. ed. México: Porrúa, 1989. p. 634637. 
4. Cerrar los noviciados en los conventos de monjas, conservándose las que actualmente existen en ellos con los capitales o dotes que cada una haya introducido, y con la asignación de lo necesario para el servicio del culto en sus respectivos templos.

5. Declarar que han sido y son propiedad de la Nación todos los bienes que hoy administra el clero secular y regular, con diversos títulos, así como el excedente que tengan los conventos de monjas, deduciendo el monto de sus dotes, y enajenar dichos bienes, admitiendo en pago de una parte de su valor, títulos de la deuda pública y de capitalización de empleos.

6. Declarar, por último, que la remuneración que dan los fieles a los sacerdotes, así por la administración de los sacramentos, como por todos los demás servicios eclesiásticos, y cuyo producto anual, bien distribuido, basta para atender ampliamente al sostenimiento del culto y de sus ministros, es objeto de convenios libres entre unos y otros, sin que para nada intervenga en ellos la autoridad civil. "Tales son en resumen, las ideas de la actual administración sobre la marcha que conviene seguir, para afirmar el orden y la paz en la República..." ${ }^{53}$

El 22 de diciembre de 1869 el general González Ortega derrotó al general Miramón en San Miguel Calpulalpan y el 1o. de enero de 1861 llegó a la ciudad de México. El 11 de enero entró en la capital el presidente Benito Juárez, dando fin a la guerra de los Tres Años. El 11 de julio se declaró Presidente Constitucional de la República a Benito Juárez. $^{54}$

Entre la legislación expedida en Veracruz por Juárez de acuerdo con el Manifiesto figuran diversas disposiciones relativas a la cuestión religiosa, conocidas con el nombre de Leyes de Reforma, a las que se suman disposiciones de 1855 y 1856 relativas a la desamortización y completadas con otras dos leyes expedidas más adelante en la Ciudad de México y que fueron la Ley de secularización de hospitales y establecimientos de beneficencia del 2 de febrero de 1861, y la Ley sobre extinción de comunidades religiosas del 26 de febrero de 1863.

A partir de la consumación de la Independencia se expidieron una serie de medidas de carácter agrario referentes a colonización, repartos de tierras, desamortización, nacionalización y explotación de terrenos. Se buscaba con ellas resolver el problema agrario, consistente en la insuficiencia de tierras y la deficiente distribución de la población en el territorio nacional. ${ }^{55}$ Entre ellas destacan las siguientes: ${ }^{56}$

\footnotetext{
53 TENA RAMÍREZ, Felipe. Leyes fundamentales..., cit., p. 636.

54 Ibidem, p. 630-634.

55 MENDIETA Y NÚÑEZ, Lucio. El problema agrario de México desde su origen hasta la época actual. México, 1923. p. 69.

56 Sobre este tema véase MEDINA CERVANTES, José Ramón. Derecho agrario. México: Harla, 1987. De su obra tomamos, en parte, la lista de las disposiciones agrarias aquí mencionadas.
} 
1. Decreto de 14 de octubre de 1823 sobre la formación de la Provincia del Istmo de Tehuantepec. Mediante este decreto se creó la provincia del Istmo, con base en los terrenos baldíos de la zona, tanto para efectos de colonización como agrícolas, al igual que el financiamiento mediante la venta de los predios. ${ }^{57}$ Se creó un distribuidor de tierras, quien con el auxilio de dos ingenieros debía levantar un plano exacto de la provincia antes de repartir y titular los lotes. El resultado de esta ley fue la entrega de la tercera parte de los baldíos a los campesinos y el resto a militares y propietarios nacionales y extranjeros. ${ }^{58}$

2. Ley general de colonización del 18 de agosto de 1824. Esta ley buscaba impulsar la colonización, tanto de nacionales como de extranjeros, de los terrenos nacionales. ${ }^{59}$

3. Ley de colonización de 1o. de abril de 1830. Esta ley fue obra de Anastasio Bustamante; se trataban aspectos de defensa territorial, industrialización y colonización de puntos deshabitados del país. ${ }^{60}$

4. Decreto del 27 de noviembre de 1846 que crea la Dirección General de Colonización. Durante el gobierno de José Mariano Salas, como presidente interino de la República, se dictó un extenso Reglamento sobre colonización, en el que se contempla la mencionada Dirección, dependiente del Ministerio de Relaciones Exteriores e Interiores. Esta Dirección estaba encargada de levantar los planos de los terrenos de la República que pudieran colonizarse, así como recabar los datos que obraban en los archivos de la clase de terreno y de su productividad, aguas, montes y minerales, salinas y clima. Los terrenos que no estuvieran en propiedad de particulares, sociedades o corporaciones estaban contemplados por el art. 8 del Reglamento de Terrenos Baldíos.

La Federación se reservaba para sí las minas descubiertas y por descubrir en los terrenos baldíos que no estuvieren poseídos al momento de su enajenación. Los terrenos motivo de la colonización serían vendidos a los colonos mexicanos o extranjeros con múltiples facilidades de pago. Las condiciones de venta también se fijaban en el Reglamento.

De los terrenos, una sexta parte quedaba a disposición del Ministerio de la Guerra para premios de militares y capitalización de sueldos. ${ }^{61}$

57 MENDIETA Y NÚÑEZ, Lucio. El problema agrario... cit., p. 70-71.

58 LEMUS GARCÍA, Raúl. Derecho agrario mexicano (sinopsis histórica). 3. ed. México: Limusa, 1978. p. 177.

59 Ley general de colonización del 18 de agosto de 1824, en OROZCO, Wistano Luis. Legislación y jurisprudencia sobre terrenos baldios. México: Imprenta de El Tiempo, 1895. p. 214-219.

${ }^{60}$ MENDIETA Y NÚÑEZ, Lucio. El problema agrario... cit., p. 71.

${ }^{61}$ El texto se encuentra, parcialmente, en Decreto del 27 de noviembre de 1846 que crea la Dirección General de Colonización, en OROZCO, Wistano Luis. Legislación... cit., p. 219-233. 
5. Ley de colonización de 16 de febrero de 1854. Obra de Antonio López de Santa Anna, se trataba de una ley de gran trascendencia, en la que se otorga por primera vez competencia en materia de colonización al Ministerio de Fomento, Colonización, Industria y Comercio, con la idea de incentivar y traer inmigrantes procedentes de Europa que fueran católicos, apostólicos y romanos, de buenas costumbres y con una profesión útil a la agricultura, industrias, artes o comercio. A los inmigrantes se les financiaba el traslado, la alimentación, la compra de instrumentos de trabajo y la exención de derechos, con la obligación de reintegrar esas sumas en el lapso de dos años, contados a partir de su llegada. Además se considerarían ciudadanos mexicanos. ${ }^{62}$

6. Decreto de 11 de enero de 1847 por el que se autoriza al gobierno para proporcionarse hasta quince millones de pesos, con hipoteca ó venta de los bienes de manos muertas. Éste fue expedido para que el gobierno mexicano pudiera hacerse de recursos en la guerra contra Estados Unidos de América, mediante la desamortización y venta de bienes hasta un monto de 15 millones de pesos. ${ }^{63}$

7. Decreto del 31 de marzo de 1856 por el que se manda intervenir los bienes eclesiásticos de la diócesis de Puebla. A partir de la expedición de la Ley Juárez, del 23 de noviembre de 1855, se inició a la revuelta de los zacapoaxtlas, el 12 de diciembre de ese mismo año, al grito de "religión y fueros". Esta revuelta fue alentada por el obispo de la diócesis de Puebla, lo que motivó la expedición del decreto del 31 de marzo, en el que se autorizaba a los gobernadores de Puebla, Veracruz y al jefe político de Tlaxcala la intervención de los bienes eclesiásticos de la diócesis de Puebla para resarcir los daños de la guerra mediante indemnizaciones en favor de la Nación. ${ }^{64}$

3.1. La Ley de desamortización de Fincas Rústicas y Urbanas de las Corporaciones Civiles y Religiosas, del 25 de junio de 1856 y su Reglamento, del 30 de julio de $1856^{65}$

Sin duda la medida más trascendente para el tema que nos ocupa es la Ley de desamortización de Fincas Rústicas y Urbanas de las Corporaciones Civiles y

62 Ley de colonización de 16 de febrero de 1854, en OROZCO, Wistano Luis. Legislación... cit., p. $233-238$.

63 Decreto de 11 de enero de 1847 por el que se autoriza al gobierno para proporcionarse hasta quince millones de pesos, con hipoteca ó venta de los bienes de manos muertas, en DUBLÁN, Manuel; LOZANO, José María. Legislación mexicana o colección completa de las disposiciones legislativas expedidas desde la independencia de la república. Ed. Oficial, Imprenta del Comercio, 1876. t. 5, n. 2.944. Su Reglamento en las p. 248-252.

64 Decreto del 31 de marzo de 1856 por el que se manda intervenir los bienes eclesiásticos de la diócesis de Puebla, en DUBLÁN, Manuel; LOZANO, José María. Legislación... cit., t. 8, n. 4.672.

${ }^{65}$ Ley de desamortización de Fincas Rústicas y Urbanas de las Corporaciones Civiles y Religiosas, del 25 de junio de 1856 y su Reglamento, del 30 de julio de 1856, en LABASTIDA, Luis G. Colección de leyes, decretos, reglamentos, circulares, órdenes y acuerdos relativos a la desamortización de los bienes 
Religiosas, del 25 de junio de 1856 y su Reglamento, del 30 de julio de 1856. Mediante estos ordenamientos se buscó poner en circulación la gran cantidad de bienes que estaba concentrada en manos de organizaciones religiosas y civiles, ${ }^{66}$ para lo cual dispuso:

a) Que todas las fincas rústicas y urbanas administradas, propiedad, o ambas, de las corporaciones civiles o eclesiásticas se adjudicarían en propiedad a los que las tuvieran arrendadas, por el valor correspondiente a la renta que en ese momento pagaban, calculada como rédito a $6 \%$ mensual. La misma adjudicación se haría a los que tenían las mencionadas fincas rústicas o urbanas a censo enfitéutico, capitalizando a $6 \%$ el canon pagado para determinar su valor. Bajo el nombre de corporaciones se comprendieron todas las comunidades religiosas de ambos sexos, cofradías y archicofradías, congregaciones, hermandades, parroquias, ayuntamientos, colegios y en general todo establecimiento o fundación que tenga el carácter de duración perpetua o indefinida.

b) Las fincas que al momento de la publicación de la ley no estuvieren arrendadas se adjudicarían al mejor postor, en almoneda celebrada ante la primera autoridad política del Partido.

c) Quedaban exceptuados de la enajenación los edificios destinados de manera inmediata y directa al servicio u objeto del instituto de esas corporaciones, aun cuando estuviera arrendada alguna parte no separada de ellos, como los conventos. Se exceptuaba también una casa que estuviera unida a los edificios y se hallará habitada por razón de oficio de quienes atendieran el objeto de la institución, como las casas de párrocos y capellanes de religiosas.

d) Las adjudicaciones y remates debían hacerse dentro de los tres meses siguientes contados a partir de la publicación de la ley. Mediante circular de 7 de julio de 1856 se excitó a las corporaciones para que procurasen la ejecución efectiva de esta ley.

Mediante circular del 7 de julio de 1856 se excitó a las corporaciones para que procurasen la ejecución efectiva de esta ley.

La Constitución de 1857, en su art. 27, establecía que la propiedad de las personas no podía ser ocupada sin su consentimiento, sino por causa de utilidad pública y previa indemnización. Se determinaban además los requisitos para la expropiación y la autoridad responsable de llevarla a cabo. Se negaba, además, la capacidad legal de las corporaciones civiles o eclesiásticas para adquirir bienes raíces, excepto para los objetivos de la institución.

de corporaciones civiles y religiosas y a la nacionalización de los que administraron las últimas. México: Tipografía de la Oficina Impresora de Estampillas, 1893. p. 3-6 y 9-13. También en FABILA, Manuel. Cinco siglos de legislación agraria en México (1493-1940). México: Banco Nacional de Crédito Agrícola, 1941. p. 103-108.

66 CASO, Ángel. Derecho agrario. Historia, derecho positivo, antología. México: Porrúa, 1950. p. 103. 
"Ninguna corporación civil o eclesiástica, cualquiera que sea su carácter, denominación u objeto, tendrá capacidad legal para adquirir en propiedad o administrar por sí bienes raíces, con la única excepción de los edificios destinados inmediata y directamente al servicio u objeto de la institución."

La Ley de Desamortización, no dejó exentos de manera explícita los bienes de las comunidades indígenas del país, cosa que sí sucedía con los de los ejidos, además de que dejaba abierta la puerta para que funcionara el denuncio sobre esos bienes. En el Reglamento de la Ley de 30 de julio de 1856, no se aclaraba nada al respecto, por lo que se recurrió a una amañada interpretación por la que los bienes de las comunidades indígenas se comprendían en los objetivos de desamortización de la Ley y se privaba a las comunidades de tales terrenos, con lo que, de hecho y de derecho, eran inexistentes y, por tanto, carentes personalidad jurídica. ${ }^{67}$

Cabe destacar que en 1858, Félix Zuloaga dio marcha atrás a esta Ley y a su Reglamento del 30 de julio de $1856 .^{68}$

Mediante decreto, se declararon nulas las disposiciones citadas $\mathrm{y}$, en consecuencia, igualmente nulas y de ningún valor las enajenaciones de los bienes que se hubieren hecho en ejecución de la citada ley y reglamento, quedando las mencionadas corporaciones "en el pleno dominio y posesión" de dichos bienes, como lo estaban antes de la expedición de la ley. ${ }^{69}$ Le correspondía entonces al Consejo de Gobierno consultar todas las disposiciones que estimase necesarias, relativas a la devolución de las alcabalas, enajenaciones de bienes pertenecientes a las corporaciones civiles, determinaciones generales acerca de arrendamientos, y demás puntos conexos.

El 1 de marzo siguiente Zuloaga expidió el Reglamento de la ley de 28 de enero de 1858 , en la parte relativa a enajenaciones de bienes raíces pertenecientes á corporaciones eclesiásticas. ${ }^{70}$

67 LEMUS GARCÍA, Raúl. Derecho agrario... cit., p. 209.

68 Su texto en Reglamento del 30 de julio de 1856, en LABASTIDA, Luis G. Colección de leyes, decretos, reglamentos, circulares, órdenes y acuerdos relativos a la desamortización de los bienes de corporaciones civiles y religiosas y a la nacionalización de los que administraron las últimas. México: Tipografía de la Oficina Impresora de Estampillas, 1893. p. 3-6 y 9-13. Véase CRUZ BARNEY, Oscar. La República Central de Félix Zuloaga y el Estatuto Orgánico Provisional de la República de 1858. México: UNAM, IIJ, 2009.

69 Decreto por la Secretaria de Hacienda del 28 de enero de 1858, declarando nulas las disposiciones contenidas en la ley de 25 de Junio de 856, y su reglamento de 30 de Julio del mismo año, sobre enajenación de los bienes eclesiásticos, Art. 1, en Arrillaga, Basilio José, Recopilación de leyes, decretos, bandos, reglamentos, circulares y providencias de los supremos poderes y otras autoridades de la República Mexicana. México: Imprenta de A. Boix, á cargo de M. Zornoza, 1864.

70 Reglamento de la ley de 28 de enero de 1858, en la parte relativa a enajenaciones de bienes raíces pertenecientes á corporaciones eclesiásticas, en ARRILLAGA, Basilio José. Recopilación de leyes, decretos, bandos, reglamentos, circulares y providencias de los supremos poderes y otras autoridades de la República Mexicana. México: Imprenta de A. Boix, á cargo de M. Zornoza, 1864. p. 46-53. 
Las disposiciones de Zuloaga multiplicaron los problemas para los poseedores de aquellas propiedades que habían pertenecido a la Iglesia en términos de su devolución y posterior recuperación ante el triunfo liberal. ${ }^{71}$

Otras disposiciones se dictaron en los meses y años subsecuentes. Así, la Circular sobre fincas de corporaciones del 9 de octubre de 1856. Nulidad de las ventas hechas por las mismas contra la ley. Se dirigía a proteger a los campesinos e indígenas en sus predios, con la facilitación de la titulación de éstos, tanto en los requisitos como en la exención de gravámenes. También la Ley de Nacionalización de los Bienes Eclesiásticos del 12 de julio de $1859,{ }^{72}$ en cuyos considerandos se afirmaba que puesto que el motivo principal de la guerra promovida y sostenida por el clero era conseguir sustraerse de la dependencia a la autoridad civil, resultaba necesario ejecutar todas las medidas necesarias para salvar la situación y la sociedad, por lo que se decretó, entre otras, las siguientes medidas que afectaban la materia agraria:

a) Entraban en el dominio de la Nación todos los bienes que el clero secular y regular administraba con diversos títulos.

b) Se suprimieron en toda la República las órdenes de religiosos regulares existentes, así como las archicofradías, cofradías, congregaciones o hermandades anexas a las comunidades religiosas, catedrales, parroquias o cualesquiera otras iglesias; asimismo se prohibió la fundación de nuevos.

\subsection{Las disposiciones sobre terrenos de comunidad en el Segundo Imperio}

El Segundo Imperio Mexicano fue muy activo en sus acciones para intentar resolver el problema existente con las comunidades indígenas. El 26 de junio de 1866 se expidió por el emperador Maximiliano de Habsburgo la Ley sobre terrenos de comunidad $y$ de repartimiento, con la que se cedía la propiedad de los terrenos de comunidad y de repartimiento a los naturales y vecinos de los pueblos a que dichas tierras pertenecían. Para ellos, los terrenos se dividirían en fracciones que serían adjudicadas a los vecinos, prefiriéndose a los pobres sobre los ricos. ${ }^{73}$

Meses después, se expide la Ley agraria del Imperio que concede fundo legal y ejido a los pueblos que carezcan del 16 de septiembre de 1866 . Como su nombre

$71 \quad$ Sobre el tema véase el artículo en Historia Mexicana de Knowlton, Robert J., "La Iglesia Mexicana y la Reforma: respuesta y resultados", Historia Mexicana, México, El Colegio de México, v. XVIII, Núm. 4, Abril-Junio, 1969, p. 532-533. Del mismo autor KNOWLTON, Robert J. Los bienes del clero y la Reforma mexicana, 1856-1910. Trad. Juan José Utrilla. México: Fondo de Cultura Económica, 1985.

72 Ley de Nacionalización de los Bienes Eclesiásticos del 12 de julio de 1859, en TENA RAMÍREZ, Felipe. Leyes fundamentales... cit., p. 638-667.

73 Su texto se encuentra en FABILA, Manuel. Cinco siglos... cit., p. 149-153. 
lo indica, mediante esta ley se establecieron los requisitos que debían cumplir los pueblos para obtener fundo legal y ejido. La solicitud debía presentarse ante los subprefectos y los terrenos así concedidos serían fraccionados y distribuidos entre los vecinos. ${ }^{74}$

Mientras tanto, el gobierno republicano expedía la Ley de 22 de julio de 1863 sobre ocupación y enajenación de terrenos baldios. Esta ley define los terrenos baldíos como los que no hubieran sido destinados a un uso público por la autoridad facultada para ello, ni cedidos por ella a título oneroso a individuo o corporación autorizada para adquirirlos. Todo habitante de la República tenía derecho a denunciar hasta 2500 hectáreas. Además, se estableció la prohibición de ejercer el denuncio por los naturales de las naciones limítrofes con México. La venta se hacía por conducto del Ministerio de Fomento. ${ }^{75}$ Señala Wistano Luis Orozco que con esta ley la tierra no fue mejor repartida, sino que por el contrario los grandes propietarios reafirmaron su poder. ${ }^{76}$

Caído el Imperio, el 31 de mayo de 1875 se expide una ley en materia de colonización que autorizó al Ejecutivo Federal para que determinara y arreglara todo lo relativo a la colonización a través de contratos celebrados con empresas particulares. Para la labor de colonización se acudiría a la inmigración de familias extranjeras, familias indígenas que se establecieran en colonias de extranjeros y familias mexicanas con asiento en colonias fronterizas. ${ }^{77}$ Años después, se expide el Decreto del 15 de diciembre de 1883 sobre colonización y compañias deslindadoras por el que se estableció, en su artículo primero, que el Ejecutivo "mandará deslindar, medir y fraccionar terrenos baldíos o de propiedad nacional que hubiere en la república, nombrando al efecto las comisiones de ingenieros que considere necesarias..." Los lotes no podrían ser en ningún caso mayores de 2500 hectáreas, las que serían asignadas a mexicanos o extranjeros mayores de edad y con capacidad para contratar. La tarea colonizadora quedaba a cargo de las compañías deslindadoras. $^{78}$

Finalmente, podemos señalar la Ley sobre ocupación y enajenación de terrenos baldios del 25 de marzo de 1894. Según Medina Cervantes, esta ley es un refinamiento de las prácticas y experiencias de la Ley de Baldios de $1863 .{ }^{79}$ Clasifica los terrenos propiedad de la Nación en baldios, demasías, excedencias y Nacionales. ${ }^{80}$ Esta clasificación se redujo solo a baldíos en 1902. La legislación del régimen de Díaz

\footnotetext{
Ibidem, p. 153-155.

Ibidem, p. 131-135.

OROZCO, Wistano Luis. Los negocios sobre terrenos baldios. Resoluciones judiciales, y estudios del lic. Wistano Luis Orozco, en el caso especial de Agustín R. Ortíz contra los Moctezuma. San Luis Potosí México: Tipografía de M. Esquivel y Cía., 1902. p. 11.

77 Su texto se halla en OROZCO, Wistano Luis. Legislación..., cit., t. 2, p. 802-806.

78 El texto puede consultarse en FABILA, Manuel. Cinco siglos..., cit., p. 183-189.

79 CERVANTES, José Ramón Medina. Derecho Agrario... cit., p. 106.

${ }^{80}$ El texto se reproduce en FABILA, Manuel. Cinco siglos... cit., p. 189-205.
} 
fue modificada en varias ocasiones para autorizar al Poder Ejecutivo Federal a ceder en forma gratuita terrenos baldíos o nacionales a los campesinos pobres que los tuvieran en su posesión; con ello se pretendía disminuir la presencia y poder de las compañías deslindadoras.

\section{La Revolución Mexicana de 1910}

La Revolución Mexicana se inició con el Plan de San Luis ${ }^{81}$ de 5 de octubre del 1910, que señaló las seis de la tarde del 20 de noviembre de 1910 para el levantamiento. En mayo de 1911 el dictador Porfirio Díaz partió de Veracruz rumbo a Europa, luego de que Francisco I. Madero fue aclamado en la capital de la República.

Las lagunas que dejo el movimiento de Francisco I. Madero trataron de llenarse con nuevos movimientos, como el de Emiliano Zapata en el estado de Morelos, quien expidió el Plan de Ayala el 28 de noviembre de $1911{ }^{82}$ en Villa de Ayala, Morelos, con el lema: "Reforma, Libertad, Justicia y Ley", suscrito por los generales Emiliano y Eufemio Zapata, Otilio E. Montaño, Jesús Morales, Próculo Capistrán y Francisco Mendoza, así como otros militares.

En el norte de la República se alzaron Orozco, y le siguieron Félix Díaz y Bernardo Reyes.

En 1913, con el movimiento de La Ciudadela, encabezado por el general Manuel Mondragón, Victoriano Huerta tomó el poder después de la renuncia y asesinato de Francisco I. Madero y José María Pino Suárez. Ante esta nueva situación, Venustiano Carranza, gobernador de Coahuila, se pronunció el 19 de febrero de 1913 y desconoció a Huerta. A Carranza se unió el gobernador de Sonora, y se inició la etapa Constitucionalista de la Revolución, que pretendía restaurar la vigencia de la Constitución de 1857. Expidieron el Plan de Guadalupe ${ }^{83}$ en la hacienda del mismo nombre, Coahuila, signado por distinguidos militares como Jacinto B. Treviño y Lucio Blanco. A partir de entonces, Carranza quedó a cargo de la legitimidad constitucional, que ejerció como presidente interino de la República y al frente del ejército constitucionalista.

El Plan, compuesto por siete artículos, se pronunciaba por el desconocimiento del general Victoriano Huerta; se refería a los Poderes Legislativo y Judicial, los gobiernos de los estados fieles al usurpador, la designación de Carranza como primer jefe del Ejército Constitucionalista y presidente interino de la República y a la convocatoria de elecciones generales una vez logrado el restablecimiento de la paz.

\footnotetext{
$81 \quad$ El texto de este plan se halla en TENA RAMÍREZ, Felipe. Leyes fundamentales... cit., p. $732-739$.

82 Ibidem 740-743.

83 Ibidem 744-745.
} 
Victoriano Huerta fue derrocado el 13 de agosto de 1914, con los Tratados de Teoloyucan se entregó la capital al Ejército Constitucionalista y se disolvió el Ejército Federal.

Tiempo antes de los tratados, se habían reunido en Torreón los representantes de las divisiones del Norte y del Nordeste para terminar con las dificultades surgidas entre éstos y Carranza. De tales reuniones resultó el Pacto de Torreón, que limitaba, a título de modificaciones al Plan de Guadalupe, los poderes del Carranza y establecía varias medidas en beneficio de los obreros y campesinos mediante el repartimiento de tierras. Este Plan lo firmaron José Isabel Robles, Miguel Silva, Manuel Bonilla y Roque González Garza L, por la División del Norte, y Antonio I. Villarreal, Cesáreo Castro, Luis Caballero y Ernesto Meade Fierro por la del Nordeste. ${ }^{84}$

Carranza no aceptó el Plan de Torreón. Sin embargo la Convención de Aguascalientes de jefes militares, inaugurada en la Ciudad de México el 14 de octubre y trasladada por Carranza a Aguascalientes, se derivó de ese plan. La Convención actuó en distintos lugares con diferentes titulares del Poder Ejecutivo; en Cuernavaca preparó el programa revolucionario que se firmó más tarde en Toluca el 24 de agosto, con diversas reformas políticas y sociales. Más adelante, la Soberana Convención Revolucionaria, integrada sobre todo por zapatistas, expidió el 18 de abril de 1916, en Jojutla, el Programa de Reformas Político-Sociales, ampliación del de Toluca.

En materia de propiedad agraria, los diferentes movimientos revolucionarios presentaron diversas propuestas y programas contenidos en los planes que prepararon. En el Plan de San Luis se señalaba el hecho de que en abuso de la Ley de Terrenos Baldios los pequeños propietarios fueron despojados de sus terrenos, por lo que los asuntos se someterían a revisión para indemnizar y restituir los predios a sus antiguos propietarios.

En el Plan de Ayala se trataba el tema de la restitución y dotación, en su caso de los terrenos, montes y aguas, a los habitantes y pueblos, siempre que éstos comprobaran su calidad de propietarios con los títulos correspondientes. Así, la declaración $6^{\mathrm{a}}$ señalaba que "los terrenos, montes y aguas que hayan usurpado los hacendados, científicos o caciques á la sombra de la tiranía y de la justicia venal entrarán en posesión de estos bienes inmuebles desde luego, los pueblos o ciudadanos que tengan sus Títulos correspondientes de esas propiedades...". Asimismo, la declaración $7^{a}$ establecía que “...la inmensa mayoría de los pueblos y ciudadanos mexicanos, no són mas dueños que del terreno que pisan, sufriendo los horrores de la miseria sin poder mejorar su condición social ni poder dedicarse á la industria o á la agricultura por estar monopolizados en unas cuantas manos las tierras, montes y aguas; por esta causa se expropiarán previa indemnización de la

$84 \quad$ TENA RAMÍREZ, Felipe. Leyes fundamentales... cit., p. 807. 
tercera parte de esos monopolios á los poderosos propietarios de ellos, á fin de que los pueblos y ciudadanos de México, obtengan egidos, colonias, fundos legales para pueblos ó campos de sembradura ó de labor y se mejore en todo y para todo la falta de prosperidad y bienestar de los mexicanos."

Finalmente se destacaba que "los hacendados, científicos, ó caciques que se opongan directa ó indirectamente al presente Plan, se nacionalizarán sus bienes y las dos terceras partes que á ellos les correspondan, se destinarán para indemnizaciones de guerra, pensiones de viudas y huérfanos de las víctimas que sucumban en la lucha del presente Plan."

Curiosamente, se propone tomar como ejemplo la legislación desamortizadora del siglo XIX.

En el Plan de Guadalupe no se hubo ningún planteamiento de corte agrario.

Con el Plan de Veracruz o Decreto declarando subsistente el Plan de Guadalupe de 26 de marzo de 1913 y lo adiciona con lo que la Revolución promete para su triunfo se propuso la restitución de las tierras a los pueblos que fueron privados de éstas, la disolución de los latifundios y la formación de la pequeña propiedad mediante leyes agrarias. ${ }^{85}$

5. El Decreto del 6 de enero de 1915, declarando nulas todas las enajenaciones de tierras, aguas y montes pertenecientes a los pueblos, otorgadas en contravención a lo dispuesto en la ley de 25 de junio de 1856

Debido a la concentración de la tierra en manos de compañías deslindadoras, los latifundios creados mediante la interpretación de la ley del 25 de junio de 1856, con la que se terminó con la propiedad de las comunidades indígenas o de repartimiento, Venustiano Carranza buscó resolver el problema mediante la devolución de los bienes a los pueblos. ${ }^{86}$

En los considerandos del decreto se señala que una de las causas más generales del malestar y descontento de las poblaciones agrícolas de México ha sido el despojo de los terrenos de propiedad comunal o de repartimiento que les fueron concedidos por el gobierno virreinal como medio para asegurar la existencia de la "clase indígena" y que a pretexto de cumplir con la ley de 25 de junio de 1856 y demás disposiciones que ordenaron el fraccionamiento y reducción a propiedad privada de aquellas tierras entre los vecinos del pueblo al que pertenecían, quedaron éstas en poder de unos cuantos especuladores.

$85 \quad$ Ibid., p. $254-258$.

${ }^{86}$ Ibid., p. 270-274. Véase también MENDIETA Y NÚÑEZ, Lucio. El problema agrario... p. 104-108. 
Lo anterior provocó que los pueblos indígenas, privados de las tierras, aguas y montes que el gobierno virreinal les concedió y las congregaciones y comunidades de sus terrenos, no han tenido otro recurso para sobrevivir que "alquilar a vil precio" su trabajo a los terratenientes.

De ahí que como un acto de elemental justicia era palpable la necesidad de devolver a los pueblos los terrenos de que habían sido despojados habiendo estado imposibilitados para defender sus derechos por falta de personalidad jurídica.

Posteriormente, mediante la Ley agraria del 24 de mayo de 1915, expedida por el General Francisco Villa y dividida en 20 artículos, se recomendaba reducir las extensiones de tierras de propiedad agraria a límites justos y a la vez distribuir de manera equitativa las excedencias entre quienes carecieran de terrenos, a través de la expedición por parte de los estados, de las leyes agrarias correspondientes, en las que se fijarían las extensiones máximas a que debía quedar sujeta la gran propiedad agraria. ${ }^{87}$ Declaraba de utilidad pública el fraccionamiento de las grandes propiedades territoriales en la extensión que como máximo señalaren los estados. ${ }^{88}$

Finalmente debemos destacar la Ley agraria de la Soberana Convención Revolucionaria con la que se aceptaba el planteamiento agrario del Plan de Ayala y rechazaba el monopolio de la tierra por latifundistas. Se insistía en la necesaria acción restitutoria de terrenos, montes y aguas a las comunidades e individuos, sujeta a que poseyeran los títulos de propiedad con fechas anteriores a $1856 .{ }^{89}$

En la Constitución de 1917 quedó plasmada la política agraria en el art. 27, cuyo texto original estuvo vigente durante cerca de 18 años, coexistiendo con igual rango con la ley del 6 de enero de 1915.

La fracción VI del artículo 27 constitucional señaló: los condueñazgos, rancherías, pueblos, congregaciones, tribus y demás corporaciones de población que de hecho o por derecho guarden el estado comunal, tendrán capacidad para disfrutar en común las tierras, bosques y aguas que les pertenezcan o que se les haya restituido o restituyeren conforme a la ley de 6 de enero de 1915.

Se modificó por primera vez primera el 10 de enero de 1934.

\section{Conclusión}

En las Indias se intentó desde un inicio que imperaran con exclusividad las leyes castellanas; sin embargo, pronto tuvieron que ceder ante la nueva realidad social

\footnotetext{
87 MEDINA CERVANTES, José Ramón. Derecho Agrario... cit., p. 137.

88 LEMUS GARCÍA, Raúl. Derecho agrario... cit., p. 261.

89 MEDINA CERVANTES, José Ramón. Derecho Agrario... cit., p. 139.
} 
que exigía preceptos de aplicación peculiar y específica para las tierras recientemente descubiertas. Así nace un nuevo derecho, el indiano, frente al castellano, también vigente.

La compleja realidad del nuevo mundo, rico en historia y tradiciones, complejo en su estructura social, lleva, junto con la formación de la propiedad particular, al desarrollo de la propiedad comunal de ciudades, villas y lugares a las que se les adjudicaban solares de propios y tierras, junta con una declaración de aprovechamiento comunal de montes, pastos y aguas.

Las autoridades virreinales se encargaron de reorganizar la situación de los diversos grupos indígenas concentrándolos en unidades urbanas a partir del año 1500 a las que les otorgaron nuevas tierras. Se promovió una colonización dirigida, de lo que se derivaron títulos de propiedad que debían protegerse en contra de los posibles abusos de los vecinos españoles. Se constituye así una forma de acumulación de propiedad privilegiada en favor de las poblaciones indígenas.

Los bienes de las comunidades indígenas no podían enajenarse, de ahí que en 1781 la Corona aclaró que los indios tenían solamente el dominio útil respecto de ellas y extendió la prohibición a las de los particulares. Podían testar disponiendo de sus bienes por esa vía, pero a falta de herederos, sucederla al pueblo de indios, nunca a españoles.

Se consideró que esta situación de propiedad privilegiada chocaba con el principio de igualdad ante la ley, por lo que mediante diversos ordenamientos se buscó poner en circulación la gran cantidad de bienes que estaba concentrada en manos de organizaciones religiosas y civiles.

Sin embargo, dichas modificaciones no solamente no resolvieron el problema de la falta de igualdad sino que la agravaron, lo que llevó a la revolución de 1910 y a las disposiciones posteriores que buscaron devolver la propiedad agraria a los pueblos.

México, enero de 2013.

\section{Referencias}

CABO MARTíN, Carlos de. Sobre el concepto de ley. Madrid: Ed. Trotta, 2000.

CASO, Ángel. Derecho agrario. Historia, derecho positivo, antologia. México: Porrúa, 1950.

CHIMALPÁHIN, Domingo de. Diario. Paleografía y traducción Rafael de Tena. México: Consejo Nacional Para la Cultura y las Artes, 2001. Colección "Cien de México".

CLAVERO, Bartolomé. Mayorazgo. Propiedad feudal en Castilla 1369-1836. 2. ed. Madrid: Siglo XXI, 1989. 
CRUZ BARNEY, Oscar. La República Central de Félix Zuloaga y el Estatuto Orgánico Provisional de la República de 1858. México: UNAM, IIJ, 2009.

DICKMANN, Renzo. Codificazione e processo legislativo. In: COSTANZO, Pasquale (Coord.). Codificazione del diritto e ordinamento costituzionale. Napoli: Facoltá di Giurisprudenza della Universitá di Camerino, 1999.

DUFOUR, Alfred. Droits de l'homme droit naturel et histoire. Paris: Presses Universitaires de France, 1991.

FABILA, Manuel. Cinco siglos de legislación agraria en México (1493-1940). México: Banco Nacional de Crédito Agrícola, 1941.

GARCÍA GRANADOS, Ricardo. La Constitución de 1857 y las Leyes de Reforma en México. México: Estudio histórico-sociológico, Tipografía Económica, 1906.

GAZZANIGA, Jean Louis. La dimension historique des libertés et droits foundamentaux. In: CABRILLAC, Remy; FRISON-ROCHE, Marie-Anne; REVET, Thierry (Coord.). Libertés et droits fondamentaux. 8. ed. París: Dalloz, 2002.

GIBSON, Charles. Los aztecas bajo el dominio español (1519-1810). trad. Julieta Campos, Siglo XXI, México, 1967.

AGUIRRE BELTRÁN, Gonzalo. Formas de gobierno indígena, Instituto Nacional Indigenista, México, 1981.

GROSSI, Paolo. Mitología jurídica de la modernidad, Trad. Manuel Martínez Neira, Madrid, Trotta, 2003.

KNOWLTON, Robert J. La Iglesia Mexicana y la Reforma: respuesta y resultados. Historia Mexicana, México, El Colegio de México, v. 18, n. 4, Abr./Jun. 1969.

KNOWLTON, Robert J. Los bienes del clero y la Reforma mexicana, 1856-1910. Trad. Juan José Utrilla. México: Fondo de Cultura Económica, 1985.

LEMUS GARCÍA, Raúl. Derecho agrario mexicano (sinopsis histórica). 3. ed. México: Limusa, 1978.

MARGADANT, Guillermo Floris. Introducción a la historia del derecho mexicano. 10. ed. México: Esfinge, 1993.

MEDINA CERVANTES, José Ramón. Derecho Agrario. México: Harla, 1987.

MENDIETA Y NÚÑEZ, Lucio. El problema agrario de México desde su origen hasta la época actual. México, 1923.

OROZCO, Wistano Luis. Legislación y jurisprudencia sobre terrenos baldios. México: Imprenta de El Tiempo, 1895. 
RICARD, Robert. La conquista espiritual de México. Trad. Ángel María Garibay. México: JusPolis, 1947.

SOLÓRZANO Y PEREIRA, Juan de. Política indiana. Madrid: Compañía Ibero-Americana de Publicaciones, 1930. t. I.

TAU ANZOATEGUI, Víctor. La codificación en la Argentina, 1810-1870. Mentalidad social e ideas jurídicas. 2. ed. Buenos Aires: Librería-Editorial Emilio J. Perrot, 2008.

TOMÁS Y VALIENTE, Francisco. El marco político de la desamortización en España. Barcelona: Ariel, 1971.

VÁZQUEZ, Josefina Zoraida. La imagen del indio en el español del siglo XVI. Xalapa: Biblioteca Universidad Veracruzana, 1991.

OROZCO, Wistano Luis. Los negocios sobre terrenos baldios. Resoluciones judiciales, y estudios del lic. Wistano Luis Orozco, en el caso especial de Agustín R. Ortíz contra los Moctezuma. San Luis Potosí, México: Tipografía de M. Esquivel y Cía., 1902.

ZAVALA, Silvio; MIRANDA, José. Instituciones indígenas en la colônia. In: Métodos y resultados de la política indigenista en México. México: Instituto Nacional Indigenista, 1954.

\section{Fuentes}

DECRETO CCVII Abolición de las mitas. Otras medidas a favor de los Indios, en Colección de los decretos y órdenes que han expedido las Cortes Generales y Extraordinarias, Reimpresa de Orden del Gobierno. Sevilla: Imprenta Mayor de la Ciudad, 1820. t. 3.

DECRETO de 11 de enero de 1847 por el que se autoriza al gobierno para proporcionarse hasta quince millones de pesos, con hipoteca ó venta de los bienes de manos muertas. In: DUBLÁN, Manuel; LOZANO, José María. Legislación mexicana o Colección completa de las disposiciones legislativas expedidas desde la independencia de la república. Ed. Oficial, Imprenta del Comercio, 1876, tomo 5, n. 2.944.

DECRETO del 27 de noviembre de 1846 que crea la Dirección General de Colonización. In: OROZCO, Wistano Luis. Legislación y jurisprudencia sobre terrenos baldios. México: Imprenta de El Tiempo, 1895.

DECRETO del 31 de marzo de 1856 por el que se manda intervenir los bienes eclesiásticos de la diócesis de Puebla. In: DUBLÁN, Manuel; LOZANO, José María. Legislación mexicana o Colección completa de las disposiciones legislativas expedidas desde la independencia de la república. Ed. Oficial, Imprenta del Comercio, 1876. t. 8, n. 4.672.

DECRETO por la Secretaria de Hacienda del 28 de enero de 1858, declarando nulas las disposiciones contenidas en la ley de 25 de Junio de 856, y su reglamento de 30 de Julio del mismo año, sobre enagenacion de los bienes eclesiásticos. In: ARRILLAGA, Basilio José. Recopilación 
de leyes, decretos, bandos, reglamentos, circulares y providencias de los supremos poderes y otras autoridades de la República Mexicana. México: Imprenta de A. Boix, á cargo de M. Zornoza, 1864.

ENCINAS, Diego de. Cedulario indiano. ed. facsimilar de la única de 1596. Madrid: Ediciones de Cultura Hispánica, 1945. t. 4.

LEY de colonización de 16 de febrero de 1854. In: OROZCO, Wistano Luis. Legislación y jurisprudencia sobre terrenos baldios. México: Imprenta de El Tiempo, 1895.

LEY de desamortización de Fincas Rústicas y Urbanas de las Corporaciones Civiles y Religiosas, del 25 de junio de 1856 y su Reglamento, del 30 de julio de 1856. In: LABASTIDA, Luis G. Colección de leyes, decretos, reglamentos, circulares, órdenes y acuerdos relativos a la desamortización de los bienes de corporaciones civiles y religiosas y a la nacionalizacion de los que administraron las últimas. México: Tipografía de la Oficina Impresora de Estampillas, 1893.

LEY de Nacionalización de los Bienes Eclesiásticos del 12 de julio de 1859, en Tena Ramírez, Felipe, Leyes fundamentales de México. 1808-1989, 15a. ed., Porrúa, México, 1989.

LEY general de colonización del 18 de agosto de 1824. In: OROZCO, Wistano Luis. Legislación y jurisprudencia sobre terrenos baldios. México: Imprenta de El Tiempo, 1895.

LEY II, Tít. IV, Lib.VI, de la Recopilación de Leyes de los Reinos de las Indias. Madrid: Viuda de Joaquín Ibarra, 1791.

LEY IX, Tít.III, Lib.VI, de la Recopilación de Leyes de los Reinos de las Indias. Madrid: Viuda de Joaquín Ibarra, 1791.

LEY VIII, Tít.III, Lib.VI, de la Recopilación de Leyes de los Reinos de las Indias. Madrid: Viuda de Joaquín Ibarra, 1791.

LEY XIIII, Tít. IV, Lib.VI, de la Recopilación de Leyes de los Reinos de las Indias. Madrid: Viuda de Joaquín Ibarra, 1791.

LEY XIX, Tít. XII, Lib. IV, de la Recopilación de Leyes de los Reinos de las Indias. Madrid: Viuda de Joaquín Ibarra, 1791.

LEY XV, Tít.III, Lib.VI, de la Recopilación de Leyes de los Reinos de las Indias. Madrid: Viuda de Joaquín Ibarra, 1791.

LEY XVIII, Tít. XII, Lib. IV, de la Recopilación de Leyes de los Reinos de las Indias. Madrid: Viuda de Joaquín Ibarra, 1791.

LEY XXVII, Tít. I, Lib. VI, de la Recopilación de Leyes de los Reinos de las Indias. Madrid: Viuda de Joaquín Ibarra, 1791.

MANIFIESTO del gobierno constitucional a la nación del 7 de julio de 1859. In: TENA RAMÍREZ, Felipe. Leyes fundamentales de México. 1808-1989. 15. ed. México: Porrúa, 1989. 
PÉREZ Y LÓPEZ, Antonio Xavier. Teatro de la Legislación Universal de España e Indias. MADRID: Imprenta de Antonio Espinoza, 1791-1798. t. XXVIII.

RECOPILACIÓN de Leyes de los Reinos de las Indias. In: Madrid, Julián de Paredes, 1681. Facsimilar, Ediciones Cultura Hispánica, Madrid, 1973.

RECOPILACIÓN de Leyes de los Reinos de las Indias. Madrid: Viuda de Joaquín Ibarra, 1791.

RECOPILACIÓN Sumaria de todos los autos acordados de la Real Audiencia y Sala del Crimen de esta Nueva España, por el doctor Eusebio Bentura Beleña, impresa en México por Felipe de Zúñiga y Ontiveros. México, 1797.

REGLAMENTO de la ley de 28 de enero de 1858, en la parte relativa a enagenaciones de bienes raices pertenecientes á corporaciones eclesiásticas. In: ARRILLAGA, Basilio José. Recopilación de leyes, decretos, bandos, reglamentos, circulares y providencias de los supremos poderes y otras autoridades de la República Mexicana. México: Imprenta de A. Boix, á cargo de M. Zornoza, 1864.

REGLAMENTO del 30 de julio de 1856. In: LABASTIDA, Luis G. Colección de leyes, decretos, reglamentos, circulares, órdenes y acuerdos relativos a la desamortización de los bienes de corporaciones civiles y religiosas y a la nacionalizacion de los que administraron las últimas. México: Tipografía de la Oficina Impresora de Estampillas, 1893.

RESOLUCIÓN de 19 de diciembre de 1856. In: LABASTIDA, Luis G. Colección de leyes, decretos, reglamentos, circulares, órdenes y acuerdos relativos a la desamortización de los bienes de corporaciones civiles y religiosas y a la nacionalizacion de los que administraron las últimas. México: Tipografía de la Oficina Impresora de Estampillas, 1893.

SOLANO, Francisco de. Cedulario de tierras. Compilación de legislación agraria colonial (14971820). México: Instituto de Investigaciones Jurídicas, UNAM, 1984. 